Ewa JURGA-WOSIK

Uniwersytet im. Adama Mickiewicza w Poznaniu

\title{
Sportowe pasje kobiet. Przyczynek do jakościowych badań nad zawartością treści w prasie regionalnej i lokalnej Wielkopolski oraz jej pogranicza
}

$\mathbf{B}_{\text {czyniają się do poznania życia wspólnoty lokalnej. Ograniczając się }}^{\text {adania nad zawartością treści w prasie lokalnej i regionalnej przy- }}$ do wąskiej problematyki, jaką są sportowe zainteresowania kobiet, autorka analizuje udział kobiet czynny (zawodniczki, trenerki) i bierny (administrowanie określonymi dyscyplinami, kibice) w sporcie uprawianym amatorsko i zawodowo. W publikacji wskazuje również na czynniki decydujące o dominacji określonej dyscypliny sportu w regionie i zastanawia się, na ile prezentowany obraz jest prawdziwy, zgodny z rzeczywistością i wyczerpuje wszystkie aspekty kobiecych zainteresowań sportem. Interesująca jest również forma ekspozycji badanych materiałów prasowych, która potwierdza, iż media lokalne i regionalne w mniejszym lub większym stopniu (w zależności od typu pisma ${ }^{1}$ ) uległy tabloidyzacji. Analizując jakościowe badania, już na wstępie należy stwierdzić, iż potrzeba uprawiania sportu przez kobiety to nie tylko wyraz ich emancypacji, rozwijania swoich zdolności czy bicia rekordów, ale współcześnie to przede wszystkim sposób na życie - to tzw. „,zdrowy styl życia”. Prasa lokalna i regionalna w tej mierze wypełniła dwie role - szerzej prezentowała sport zawodowy i amatorski, a w mniejszym stopniu zachęcała czytelnika do uprawiania sportu (promowanie „zdrowe stylu życia” to średnio 2 artykuły na 18 z ogółu kategorii „sport”).

$\mathrm{Na}$ podstawie analizy zawartości treści wielkopolskich czasopism w latach 1989-2011, można wskazać, iż problematyka kobieca obejmo-

1 Szerzej: E. Jurga-Wosik, Typologia mediów lokalnych $w$ teorii i praktyce, artykuł złożony do druku, WNPiD w Poznaniu. 
wała dwa nurty ${ }^{2}$. Pierwszy z nich przedstawiał historyczny i współczesny wizerunek kobiety, a drugi poruszał kwestie kobiece na tle zjawisk i wydarzeń politycznych, ekonomicznych oraz społecznych. O ile w pierwszej dekadzie III RP prasa regionalna i lokalna potwierdzała istnienie stereotypowo postrzeganych ról kobiecych, o tyle, opierając się o badania z 2011 roku nastąpiło zrównanie ról kobiecych i męskich w wielu aspektach życia codziennego. Publikacja ta ma na celu pogłębienie omówionej wcześniej przez autorkę problematyki, ale tylko w kontekście przemian jakościowych, jakie zaszły w prezentowaniu publikacji o tematyce sportowej na łamach drukowanej prasy regionalnej i lokalnej Wielkopolski oraz jej pogranicza, w latach 1989-2012, które odnoszą się wprost do kobiet. Pole badawcze wykazało szerokie spektrum sportowych pasji kobiet, a przytoczone przykłady potwierdzają aktywny tryb życia kobiet.

Publikacja ta skupia się na prezentowaniu wspomnianych już badań jakościowych, których wnioski odnośnie leszczyńskiego regionu wydawniczego, będącego częścią Wielkopolski, zostały już czytelnikowi zaprezentowane $^{3}$. Niniejsze opracowanie ukazuje sposób i formę dyskursu podjętego w prasie lokalnej i regionalnej Wielkopolski odnośnie materiałów prasowych poświęconych kobietom uprawiającym sport amatorsko i zawodowo oraz zainteresowanych sportem zawodowo bądź prywatnie. W odrębnym artykule zostaną zaprezentowane statystyczne badania prezentujące ilość i ekspozycję materiałów, stosowanie gatunków i rodzajów tematów, obejmujące sportowe zainteresowania zarówno kobiet, jak i mężczyzn ${ }^{4}$.

Prasa lokalna lat dziewięćdziesiątych szeroko rozpisywała się o mężczyznach wykonujących zawodowo określone dyscypliny sportowe (najczęściej piłka nożna, żużel). Dowodem tego mogą być przeprowadzone w 1997 roku jubileuszowe obchody kościańskiego sportu, kiedy wręczono nagrody mniej i bardziej znanym sportowcom z regionu leszczyń-

2 E. Jurga-Wosik, Women in the local Press in south - west Wielkopolska, w: Some issues on women in political, media and socio - economic space, red. I. Andruszkiewicz, A. Balczyńska-Kosman, Poznań 2012, s. 115-137.

3 E. Jurga-Wosik, Prasa lokalna $w$ leszczyńskim regionie wydawniczym. Przyczynek do badań nad zawartościq treści w kontekście sportowych wydarzeń medialnych, ze szczególnym udziałem kobiet, „Przegląd Politologiczny” 2012, nr 4.

4 Publikacja będzie pokłosiem konferencji Modele dziennikarstwa we współczesnym świecie, zorganizowanej w Krakowie 16-17.04.2013 r. 
skiego i zasłużonym działaczom szerzenia kultury fizycznej ${ }^{5}$. Niestety kobiet nie było wśród 90 osób nagrodzonych, a wyróżnienia dotyczyły piłki nożnej. W 2012 roku już są nagradzane kobiety sportowcy z powiatu kościańskiego. Zmienia się również popularność dyscyplin. Piłka nożna (KS „Obra”) uplasowała się na dalszych miejscach (wynika z analizy treści) za takimi dyscyplinami sportowymi jak - karate (Klub Karate "Gottsu”), trójbój siłowy, lekkoatletyka i tenis ${ }^{6}$. Nie znaczy to, że kobiety według mediów lokalnych w latach dziewięćdziesiątych nie uprawiały sportu lub nie odnosiły sukcesów w danych dyscyplinach. W 1996 roku w „Przeglądzie Górowskim” ukazał się artykuł pt. I Sportowy Plebiscyt PG rozstrzygnięty!, w którym to na dalszych miejscach uplasowały się kobiety sportowcy - Wioletta Pilarska i Ewa Kozłowska (szósta pozycja, tenis stołowy) oraz Monika Zakaszewska (siódma pozycja, tenis stołowy) ${ }^{7}$. W „Gazecie Kościańskiej” można było przeczytać o kibicach z regionu leszczyńskiego, którzy uczestniczyli w jednym z największych turniejów - Grand Prix Pucharu Świata we florecie kobiet w Gdańsku w 2006 roku $^{8}$. Z drugiej strony - kobiety - sportowcy, dziękują swoim kibicom za doping. Kajakarka Beata Mikołajczyk, złota medalistka, spotkała się po zwycięskim starcie z kibicami na zawodach Pucharu Świata, na poznańskiej Malcie ${ }^{9}$. Kobiety również odnoszą sukcesy w olimpiadach propagujących wiedzę o sporcie ${ }^{10}$.

Problematyka kobieca po 1989 roku i w pierwszej połowie lat dziewięćdziesiątych rzadko była eksponowana na łamach prasy lokalnej. Kobiety uprawiające sport niekiedy pojawiały się w działach poświęconych kronice sportowej regionu wydawniczego ${ }^{11}$. W 1994 roku w „Rydzynie Tu i Teraz" opublikowano artykuł odnośnie Turnieju Nauczycieli

S. Dybuk, „Wiadomości Kościańskie”, 12.12.1997, s. 56-57.

Sportowcy z nagrodami, „Gazeta Kościańska”, nr 22, 30.05.2012, s. 30.

J. Dwornik, I Sportowy Plebiscyt PG rozstrzygnięty!, „Przegląd Górowski”, nr 6, 3.04.1996, s. 1, 6-7.

8 Kibicowali florecistkom, „Gazeta Kościańska”, nr 22, 31.05.2006, s. 26.

9 Dopingowali kajakarzy, „Gazeta Kościańska”, nr 8, 24.05.2006, s. 30.

${ }^{10}$ Kościaniacy na olimpijskim szlaku, „Gazeta Kościańska”, nr 48, 30.11.2005, s. 24.

11 „Rydzyna Tu i Teraz”, nr 6, 25.10.1997, s. 12. Przykładem edycji pism, w których nie było informacji sportowych może być - „Przegląd Górowski”, nr 12, 26.06.1992; „Gazeta Wschowska”, nr 1, 24.12.1994; „Nowiny Niechlowskie”, grudzień 1998; „Wiadomości Jutrosińskie”, nr 71, 1999; „Wieści Gminne”, nr 1, m-ce I-II, 1999. 
w Koszykówce im. Leszka Szlachetki w Bojanowie, podczas którego „wielką atrakcją był koszykarski show w wykonaniu zawodniczek poznańskiej Olimpii", a także opublikowano notatkę dotyczącą Biegu Niepodległości w Lesznie, w którym to „bardzo dobrze pobiegły dziewczęta z Kaczkowa”, zajmując piąte miejsce ${ }^{12}$. Jednak w pierwszej połowie lat dziewięćdziesiątych prasa głównie skupiała się na bieżących sprawach politycznych i administracyjnych regionu, podnosząc przy tym walor lokalnych i historycznych wydarzeń (np. w „Gazecie Wschowskiej” opublikowano cykl artykułów poświęconych funkcjonowaniu powiatu wschowskiego). Przeprowadzone badania metodą analizy zawartości treści w latach 1989-1991 dowodzą - jak wskazuje Ryszard Kowalczyk - iż kobieta rzadko była bohaterką publikacji w prasie lokalnej ówczesnego województwa poznańskiego ${ }^{13}$. Wśród przeanalizowanych $201 \mathrm{nu}-$ merów prasy lokalnej, tylko w 34, czyli w 17\% odnotowano materiały poświęcone kobietom - zatem statystycznie występowały one w 1,7 na 10 numerów prasy lokalnej. Powyższe analizy można uzupełnić o badania przeprowadzone przez autorkę w oparciu o prasę leszczyńskiego regionu wydawniczego ${ }^{14}$, dzięki którym można stwierdzić, iż dekadę

12 „Rydzyna Tu i Teraz”, nr 4, 22.12.1994, s. 18-19.

13 R. Kowalczyk, Obraz kobiety w prasie lokalnej na progu transformacji systemowej Polski w latach 1989-1991, w: Między historia, politologia a medioznawstwem, red. T. Wallas, Poznań 2010, s. 157.

${ }^{14}$ Szerzej o leszczyńskim regionie wydawniczym: E. Jurga-Wosik, Dwie dekady przeobrażeń mediów lokalnych poludniowo-zachodniej Wielkopolski, „Środkowoeuropejskie Studia Polityczne” 2012, nr 1, s. 295-319. W 1989 r. liczba leszczyńskich tytułów sięgała dziewięciu, a w grudniu 1998 r. - pięćdziesięciu czterech (lokalnych było -6 , a sublokalnych - 48). Natomiast w czerwcu 1999 roku, już w nowych realiach administracyjnych było 49 pism (lokalnych -16 , sublokalnych -33 ). W nowe tysiąclecie weszło 58 tytułów (lokalnych - 21, sublokalnych - 37). W 2009 roku liczba tytułów zmniejszyła się do 34 (lokalnych -19 , sublokalnych - 15). Natomiast w latach 1989-2011 w powiatach - leszczyńskim, gostyńskim, kościańskim, rawickim oraz górowskim (woj. dolnośląskie) i wschowskim (woj. lubuskie) - ukazało się łącznie 103 czasopisma (wraz z prasą parafialną - 14 tytułów), w tym tytułów lokalnych -43 i sublokalnych -60 . W okresie dwóch dekad kolportowano w Lesznie i powiecie leszczyńskim - 33 tytuły lokalne oraz w powiecie gostyńskim -20 , powiecie kościańskim -18 , powiecie rawickim -17 oraz powiecie górowskim - 15 i powiecie wschowskim - 14. Warto też wspomnieć o silnych związkach prasy lokalnej Kościana z powiatem wolsztyńskim, gdzie w ostatnim dwudziestoleciu ukazało się 9 tytułów oraz $\mathrm{z}$ powiatem grodziskim - w liczbie 12 tytułów. Z kolei Gmina Kobylin skorzystała z włączenia jej do powiatu krotoszyńskiego w 1999 r., w której to rozpowszechniano 6 tytułów. Niniejsze dane pomijają prasę branżową 
później w każdym numerze poszczególnych tytułów, występuje już sfera kobieca, która łączy się ze sportowym zacięciem dziewczynek i młodych kobiet, a rzadziej pań po 40 roku życia. Natomiast dosyć zintensyfikowany obraz zaangażowania kobiet - kibiców, pojawia się w czerwcu 2012, co jest efektem przejściowym, choć obrazuje inne zjawisko - społeczne zaangażowanie w Mistrzostwa Europy w Piłce Nożnej.

Analiza zawartości treści miała charakter pilotażowy i była przeprowadzana w trzech turach. Pierwsze badania objęły 7\% egzemplarzy tytułów lokalnych (378) z lat 1998-2001 ${ }^{15}$, a drugie skoncentrowały się na 2011 roku (styczeń-sierpień), na najbardziej nośnym tytule leszczyńskiego regionu wydawniczego - tygodniku „Panoramie Leszczyńskiej”. Przeanalizowano w „Panoramie Leszczyńskiej” numery od 1 do 33 (średni jednorazowy nakład tytułu wynosił w styczniu 2010 roku 33450 egz., przy sprzedaży 23386 egz., a w sierpniu 2010 roku 32341 egz., przy sprzedaży 20895 egz. - dane ZKDP) ${ }^{16}$. Trzecia tura badań objęła lokalną i regionalną drukowaną prasę Wielkopolski i jej pogranicza. Drogą losową analizie poddano 150 tytułów (głównie dzienniki i tygodniki), uwzględniające trzy miesięczne badania (próba losowa, wyjątkiem był 2012 r. $^{17}$ ), w następujących okresach: styczeń-marzec (1993, 1995, 2003, 2009), kwiecień-czerwiec (1992, 1996, 2006, 2008, 2012 r. do 15 lipca z uwagi na Euro 2012), lipiec-wrzesień (2002, 2007, 2011), październik-grudzień (1994, 1997, 2004, 2005, 2010). Warto nadmienić, iż zarówno w latach 1989-1991, na co wskazują badania przeprowadzone przez Ryszarda Kowalczyka ${ }^{18}$, tak i w latach 1998-2001, częściej problematyka kobieca występowała w dziennikach i tygodnikach, aniżeli w miesięcznikach czy kwartalnikach. Stąd też w latach 2011-2012, autorka, szczególną uwagę skupia na dziennikach i tygodnikach Wielkopolski (6 dzienników i 32 tygodniki) ${ }^{19}$.

(ok. 15 tytułów prywatnych związanych z sektorem sportowym i również tyle z reklamowym w okresie dwóch dekad) oraz gazetek szkolnych.

15 E. Jurga-Wosik, Problematyka kobieca w prasie lokalnej, „Przegląd Politologiczny" 2011, nr 2, s. 133-141.

16 E. Jurga-Wosik, Women ..., op. cit., s. 115-137.

17 Cezura czasowa objęta badaniem została narzucona ze względu na Mistrzostwa Europy w Piłce Nożnej Euro 2012.

18 R. Kowalczyk, Obraz..., op. cit., s. 157-158.

19 Badane publikacje pochodzą w części z czasopism, z prywatnych zbiorów autorki oraz są wynikiem monitoringu prasy przeprowadzonego na zlecenie autorki przez Press Service Monitoring Mediów w Poznaniu - stąd, w niektórych odnośni- 
Preferowanymi gatunkami dziennikarskimi prezentującymi sportowe pasje kobiet są niezmiennie od końca lat osiemdziesiątych gatunki o dominancie informacyjnej (najczęściej wzmianka jako informacja o pojedynczym fakcie, notatka jako informacja poszerzona, wiadomość prasowa jako informacja pełna, sylwetka prasowa, wywiad, reportaż informacyjny), które stanowią blisko 90\% wszystkich wypowiedzi dziennikarskich. Pozostałe formy mają znamiona publicystyki, a jest to zazwyczaj reportaż publicystyczny, artykuł publicystyczny i felieton oraz rzadziej - komentarz prasowy bądź esej. Kobietę i jej sportowe pasje przedstawiano na łamach tytułów w szczególny sposób. Podkreślano nie tylko determinację kobiet w przypadku uprawiania sportu, ale konfrontowano ich zaangażowanie $\mathrm{w}$ porównaniu $\mathrm{z}$ mężczyznami. Wymownym przykładem jest stwierdzenie dziennikarza „Naszego Jutra” w 1998 roku, iż „w klubie jest również pierwsza odważna dziewczyna z Włoszakowic Magda Zarabska" 20 . W artykule $\mathrm{z}$ lat dziewięćdziesiątych można było również przeczytać - „w strzelaniu królewskim I miejsce zajęła Irena Chomska uzyskując tytuł Królowej 1998 Roku. Pierwszą Damą została Urszula Cieśla, a Drugą Damą Janina Bereszyńska" "21. Kobiety rozwijają swoje sportowe pasje czynnie, coraz częściej w dyscyplinach cieszących się dotychczas zainteresowaniem głównie mężczyzn ${ }^{22}$. Prasa lokalna donosiła, iż ,[...] z trzema medalami wróciły zawodniczki Polonii Leszno z Tarnowa, gdzie rozgrywane były historyczne - I Młodzieżowe Mistrzostwa Polski Kobiet w Boksie"23. Inna wypowiedź wskazuje na kolejny męski sport - żużel. W 2012 roku, w Racing Club Leszno jeździła amatorsko Sandra Bogacz, ,[...] najstarsza w grupie i zarazem jedyna dziewczyna"24.

kach do konkretnych tytułów brak jest określonego numeru dystrybuowanego czasopisma, gdyż Press Service archiwizuje publikacje, biorąc pod uwagę wyłącznie tytuł pisma i datę publikacji.

${ }^{20}$ Podsumowanie osiagnięć sportowych w LKS „Btękitni” Osowa Sień, „Nasze Jutro", nr 93, luty 1998, s. 34.

${ }^{21}$ Z życia Kobiecego Towarzystwa Strzeleckiego, „Witryna Śmigielska”, nr 13, 9.07.1998, s. 11.

${ }^{22}$ M. Cwojda, Jeszcze o niej ustyszycie, „Panorama Leszczyńska”, nr 16, 21-27.04.2011, s. 53; Kobiety atakujq, „Panorama Leszczyńska”, $\mathrm{nr}$ 17, 28.04-4.05.2011, s. 45; Tęcza czeka na trenera, „Panorama Leszczyńska”, nr 32, 11.08-17.08.2011, s. 38; Włodarczyk wcale nie musiała, „Panorama Leszczyńska”, nr 33, 18.08-24.08.2011, s. 38.

23 „Panorama Leszczyńska”, nr 23 (1113), 7.04-12.04.2001, s. 31.

${ }^{24}$ M. Cwojda, Gtowa petna zapalu, „Panorama Leszczyńska”, $\operatorname{nr} 27$, 5.07-11.07.2012, s. 38 . 
Z kolei w Kościanie kobiety grają w piłkę nożną (mają od 11 do 19 lat) tworząc Futsal Klub Feniks Team ${ }^{25}$. Dziennikarze - sprawozdawcy sportowi, nawiązują również do atutów kobiecości. W „Kobylinie. Piśmie Samorządu Miasta i Gminy" w 1998 roku zamieszczono komentarz odnośnie zapasów kobiet - ,[...] jest to dyscyplina niewątpliwie dynamiczna, efektowna, widowiskowa i posiadająca duże walory estetyczne, niespotykane w zapasach męskich"26. Wypowiedź ta posiada również walor seksizmu ${ }^{27}$. Warto nadmienić, że elementy seksizmu można znaleźć częściej (w postać tradycyjnej ${ }^{28}$ i nowoczesnej ${ }^{29}$ ) w publikacjach niedziennikarskich (samoistne zdjęcia, anegdoty o kobietach) niż wiadomościach dziennikarskich. W przypadku samoistnych zdjęć, przedstawiających atrakcyjne kobiety, pojawia się przekonanie, iż cechy fizyczne kobiet, stanowią podstawowe kryterium oceny ich wartości społecznej. Dyskryminacja kobiet przybiera różne formy. W prasie lokalnej występuje jako tzw. „rażąca niesprawiedliwość” (artykuły opisujące przemoc domową wobec kobiet czy pozbawienie życia kobiet) ${ }^{30}$, subtelna dys-

${ }^{25}$ Dziewczyny z charakterem, „Gazeta Kościańska”, nr 22, 30.05.2012, s. 1 i 17.

26 J. Lindner, Zapasy kobiece, „Kobylin. Pismo Samorządu Miasta i Gminy”, listopad-grudzień 1998, s. 30.

27 J. Miluska, Kobiety w przestrzeni publicznej, w: Między historia, politologia a medioznawstem. Wybór problemów, red. T. Wallas, Poznań 2010, s. 117. Zdaniem J. Miluskiej: „Tradycyjny seksizm podkreśla stereotyp kobiet jako osób mających niskie kompetencje, popiera tradycyjne role płciowe oraz odmienne traktowanie kobiet i mężczyzn. Współcześnie seksizm przejawia się zaprzeczeniem istnienia dyskryminacji kobiet, nieprzychylnym nastawieniem do roszczeń kobiet w zakresie ich równouprawnienia oraz negatywną postawą wobec specjalnych przywilejów kobiet. Neoseksizm to akceptacja hierarchicznych relacji między mężczyznami i kobietami, wspierających interesy mężczyzn. $Z$ kolei ambiwalentny seksizm stanowi połączenie seksizmu łagodnego (tradycyjny pogląd na temat cech kobiet) i wrogiego (przekonanie o niższości kobiet w stosunku do mężczyzn)".

${ }^{28}$ O kastracji kocurów i sterylizacji kotek, „Panorama Leszczyńska”, nr 10, 10.03-16.03.2011, s. 10.

29 A. Maćkowiak, Nie bojq sie wyzwań, „Panorama Leszczyńska”, nr 16, 21.04-27.04.2011, s. 19; Nauczycielki z Gostynia pozuja do kalendarza. Pani od urody, „Panorama Leszczyńska”, nr 17, 28.04-4.05.2011, s. 22.

30 Biegli: wiedziat, że zabija, „Panorama Leszczyńska”, nr 1, 5.01-12.01.2011, s. 12; Bogdan K. kupit bagnet, by zabić żonę, „Panorama Leszczyńska”, nr 17, 28.04-4.05.2011, s. 13; Ciało plywało w Baryczy, „Panorama Leszczyńska”, nr 9, 3.03-9.03.2011, s. 12; Chciat pokazać jak sie jeździ, „Panorama Leszczyńska”, nr 16, 21.04-27.04.2011, s. 11; Dwa gesty w życiu Anny, „Panorama Leszczyńska”, nr 11, 17.03-23.03.2011, s. 11; A. Kempa, Konflikty w rodzinie, „Gazeta Rawicka”, 
kryminacja (np. żarty o kobietach w rubryce Zwierzyniec, w „Panoramie Leszczyńskiej") ${ }^{31}$ oraz ukryta dyskryminacja (np. tokenizm ${ }^{32}$, który dotyka kobiety sprawujące eksponowane stanowiska, potwierdza to przykład Urszuli Ranke ${ }^{33}$ ). Sport kobiet również wpisał się w ten nurt. W 2012 roku można przeczytać w „Panoramie Leszczyńskiej” o biegaczkach, które nie tylko przeszły kurs samoobrony z uwagi na agresywnego ekshibicjonistę pojawiającego się w lasach Karczmy Borowej, ale również - przyczyniły się do jego zatrzymania ${ }^{34}$.

Sportowe pasje kobiet na łamach prasy lokalnej mają zwykle wydźwięk lokalny, choć epizody międzynarodowe również wpisały się w regionalną historię sportu. Sukcesy w sporcie odnoszą zazwyczaj młode dziewczyny (uczennice), o czym chętnie informują media lokalne. W „Gazecie Kościańskiej” w 2005 roku zamieszczono informację, iż „[...] zespół z Poznania tworzą w większości bardzo młode dziewczyny, ale o dobrych warunkach"35. W drugiej dekadzie lat dziewięćdziesiątych, kobiety - sportowcy odnosily zwykle sukcesy na poziomie gminy i województwa. W 1997 r. w „Słowie Ziemi Wschowskiej” można przeczytać - ,[...] w wyniku przeprowadzonych dwóch turniejów klasyfikacyjnych

nr 8, sierpień 2001, s. 17-18; M. Krzyżanowska-Sołtysiak, Zginęty dzieci, rodzice i babcia, „Panorama Leszczyńska”, nr 24, 10.06-16.06.2011, s. 14; Nikt się nie dowie, „Panorama Leszczyńska”, nr 7, 17.02-23.02.2011, s. 12; Podwójne zabójstwo w Lechitowie, „Panorama Leszczyńska”, nr 7, 17.02-23.02.2011, s. 12; Przypalali ja papierosem, „Panorama Leszczyńska”, nr 32, 11.08-17.08.2011, s. 13; Rowerzystka walczy o życie, „Panorama Leszczyńska”, nr 6, 10.02-16.02.2011, s. 1; Studentka zarzuca radnemu molestowanie, „Panorama Leszczyńska”, nr 1, 5.01-12.01.2011, s. 13; Tylko pamiętaj, że cię kocham, „Panorama Leszczyńska”, nr 25, 22.06-29.06.2011, s. 13; Wujek zgwatcit $w$ samochodzie?, „Panorama Leszczyńska”, $\mathrm{nr} 32$, 11.08-17.08.2011, s. 3; Zarzut zabójstwa, „Panorama Leszczyńska”, nr 15, 14.04-20.04.2011, s. 1; Zemsta ucznia za jedynkę, „Panorama Leszczyńska”, nr 5, 3.02-9.02.2011, s. 11; Zginęta cała rodzina, „Panorama Leszczyńska”, nr 24, 10.06-16.06.2011, s. 1 .

31 B. Skrzypczak, Zwierzyniec, „Panorama Leszczyńska”, nr 26, 28.06-4.07.2012, s. 32 .

32 J. Miluska, op. cit., s. 118. Tokenizm wyjaśnia konsekwencje bycia członkiem mniejszościowej grupy społecznej, która się wyróżnia i jest pozbawiona faktycznej władzy.

${ }^{33}$ H. Zbierski, Rozmowa z Przewodniczaca RM Śmigla, „Witryna Śmigielska”, nr 13, 9.07.1998, s. 4-5.

34 A. Maćkowiak, Biegaczki mogq odetchnać z ulgq?, „Panorama Leszczyńska”, 28.06-4.07.2012, s. 12.

35 C. Orlik, Taśma po naszej stronie, „Gazeta Kościańska”, nr 49, 7.12.05, s. 30. 
została powołana 6 osobowa kadra województwa leszczyńskiego w tenisie stołowym, w kategorii młodzików. Z klubu Tajfun Lgiń znaleźli się

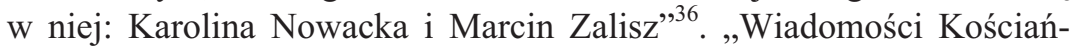
skie" w 1998 r. donosiły o zawodach strzeleckich z broni małokalibrowej, organizowanych przez miejscowy LOK, podczas których wśród seniorów na trzecim miejscu triumfowała Bożena Szczawik-Musiał ${ }^{37}$. Z kolei w Dębcu Nowym, na jeziorze Wonieść, odbyły się regaty w klasie Omega, wśród zwycięskiej załogi, składającej się z trzech osób była jedna kobieta - Barbara Tumasz ${ }^{38}$. Na tym samym jeziorze w 2012 r. rozstrzygnięto Wędkarski Puchar Lata, w których to zawodach wzięła udział siedmioosobowa grupa dzieci i młodzieży, wśród których Aleksandra Bartkowiak zajęła drugie miejsce ${ }^{39}$. Kobiety odnoszą sukcesy w tenisie stołowym (np. II miejsce w klasyfikacji indywidualnej zajęła Magdalena Nawrot, w turnieju: VI rzut klasy A w Lginiu 2001 r.) i koszykówce juniorek (najskuteczniejszą zawodniczką turnieju wojewódzkiego w 2001 r. była Agnieszka Pluntke ze Wschowy, zdobywając 52 pkt.), o czym można przeczytać w „Słowie Ziemi Wschowskiej”40. Tenis stał się też cyklicznym turniejem dla 14-latków i młodszych dzieci, odbywających się na kortach „Akwawitu” w Lesznie ${ }^{41}$. Z kolei w „Gazecie Wschowskiej” w 1996 r. opublikowano, iż „,[...] w Szczecinku odbyły się mistrzostwa Polski LZS oraz I runda Pucharu Polski w biegach przełajowych. W zawodach tych startowali biegaczki i biegacze LKS »Błękitni« Osowa Sień. Wyniki: młodziczki - Agnieszka Zawadzka $4 \mathrm{~m}$ [...] juniorki mł. Anna Matys $7 \mathrm{~m}$ [...] juniorki - Agnieszka Hornicka $17 \mathrm{~m}$,42. O ile kadetki ze SP $\mathrm{nr} 1$ we Wschowie pokonały w koszykówce swoje rywalki z Odry Wrocław, to o tyle młodziczki przegrały. Dziennikarz Karol Czyżyk, skomentował - „dziwna jest ta porażka, bowiem w pierwszym meczu tych drużyn w Szprotawie, młode

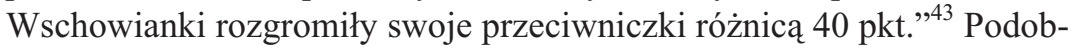
ne niezadowolenie $\mathrm{z}$ uzyskanego wyniku zostało ujęte $\mathrm{w}$ sprawozdaniu

36 Młodzi sportowcy, „Słowo Ziemi Wschowskiej”, nr 12, 20.06.1997, s. 18.

37 „Wiadomości Kościańskie”, nr 7-8, lipiec-sierpień 1998, s. 70.

38 Ibidem.

39 Młodzieżowy Puchar Lata, „Gazeta Kościańska”, nr 27, 4.07.2012, s. 30.

40 „Słowo Ziemi Wschowskiej”, nr 7-8, 13.04.2001, s. 15.

41 Po raz trzeci, „ABC”, nr 61, 4.08-7.08.2000, s. 23.

42 K. Czyżyk, Biegi przełajowe, „Gazeta Wschowska”, nr 3, Wielkanoc 1996, s. 44.

43 Ibidem. 
z II Pucharu Wielkopolski w Karate Sportowym w 2009 r. (w związku z turniejem rankingowym Wielkopolskiego Związku Karate), a zamieszczonym w „Nowej Gazecie Gostyńskie”. Dziennikarz wówczas stwierdził - „startujący zawodnicy z gostyńskiego karate TKKF »Tęcza« wypadli nieco poniżej oczekiwań, ale pokazali, że są zawodnikami liczącymi się w walce o miejsce na podium [...] najlepiej spisały się dziewczęta [...] - Weronika Chwastyniak, Monika Chwastyniak, Aleksandra Nojman [...] wywalczyły po zaciętej walce srebrne medale"44. Dziennikarze również są rozczarowani wynikami kobiet w szybownictwie. Mistrzostwa Polski w klasie otwartej w Lesznie w 2012 r. nie wyniosły kobiet na podium, co więcej ,[...] kiepsko była reprezentowana słaba [nie piękna - od aut.] płeć - w KZS startowały 3 panie, najwyżej na 12 miejscu została sklasyfikowana Joanna Biedermann (A. Nadwiślański), leszczynianka Bożena Demczenko ukończyła zawody na 23 miejscu”45. Los koszykarek z „Tęczy” pomimo zwycięstwa w 2012 r. również nie był klarowny. W „Panoramie Leszczyńskiej” można przeczytać - „niezwykle cenne zwycięstwo zapisała na swoim koncie leszczyńska Tęcza, która w Rawiczu - Sarnowie rozgromiła Odrę Brzeg 73:37. Leszczynianki [...] nie mogą być pewne ligowego bytu"46. Do tego materiału nawiązuje artykuł opisujący problemy finansowe klubu „Tęcza"47. Koszykarki jednak mają nadzieję, że w „Tęczy” będą mogły jeszcze grać, uzasadniając - „[...] bo Leszno jest fajnym miejscem na grę w koszykówkę [...]. Tęcza może nie płaci dużo, ale za to regular-

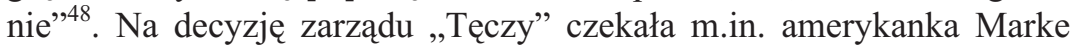
Freeman, najskuteczniejsza zawodniczka, która otrzymała już zaproszenie na „California Camp”, a w konsekwencji może otrzymać angaż WNBA, jak informowały media ${ }^{49}$. Innym razem, dziennikarz Mariusz Cwojda wnioskuje - „[...] próbowałem dowiedzieć się, jak w przyszłym sezonie będą wyglądać ligowe rozgrywki w ekstraklasie kobiet. Konia

44 M. Sobkowiak, Medale dla gostyńskich karateków, „Nowa Gazeta Gostyńska" 2009, nr 1, s. 9.

45 Nie było silnych na Nieradkę, „Panorama Leszczyńska”, nr 22, 31.05-5.06.2012, s. 46.

46 Koszykówka, „Panorama Leszczyńska”, nr 16, 19.04-25.04.2012, s. 38.

47 M. Cwojda, Mróz i Skanska pomoga Tęczy?, „Panorama Leszczyńska”, nr 20, 17.05-23.05.2012, s. 46.

48 Ibidem.

49 Tęczowa niepewność, „Panorama Leszczyńska”, nr 23, 6.06-13.06.2012, s. 46 . 
z rzędem temu, kto potrafi udzielić odpowiedzi. Nikt nic nie wie"50. Ten sam dziennikarz niespełna dwa miesiące później stwierdza - „stało się najgorsze - we wtorek pożegnaliśmy w Lesznie ekstraklasę żeńskiego basketu [...] za chwilę podobny los spotka piłkarzy leszczyńskiej Polonii. Tym sposobem hasło reklamowe »Leszno miastem sportu« proponuję zmienić na »Leszno bez sportu« [...] Urząd miasta [...] nie ma pomysłu na sport [...] szczyci się posiadaniem 70 stowarzyszeń sportowych. Miasta podobnej wielkości co Leszno (Głogów, Świdnica, Starogard Gdański, Skierniewice) nie mają więcej niż 15 stowarzyszeń",51.

Informacje o kobietach uprawiających sport często powstają przy okazji omawiania innego tematu (np. lokalnych uroczystości), ale dają również obraz popularności określonych dyscyplin sportowych. Zawody sportowe dla dzieci i młodzieży lub dla określonych grup zawodowych (np. nauczycieli, handlowców) są najczęściej organizowane podczas różnego rodzaju mistrzostw, imprez okolicznościowych i wakacyjnych obozów sportowych. Podczas tego typu wydarzeń medialnych dominuje tenis stołowy i lekkoatletyka, a w dalszej kolejności - piłka siatkowa, koszykówka, piłka nożna dziewcząt, karate, ju-jitsu, judo, a także zawody strzeleckie $^{52}$. W 2012 roku, jak podała „Gazeta Mosińsko-Puszczykow-

50 M. Cwojda, Bagienko pod koszem, „Panorama Leszczyńska”, nr 21, 24.05-30.05.2012, s. 38 .

51 M. Cwojda, Tęczowa klęska, „Panorama Leszczyńska”, nr 28, 12.07-18.07.2012, s. 40 .

52 F. Bogdanowicz, Turniej Tenisowy, „Przegląd Górowski”, nr 2, 31.01.1993, s. 4-5; Bruce Lee w spódnicy, „Głos Wagrowiecki”, 20.06.2012, s. 28; J. Dwornik, Tenis stołowy, „Przegląd Górowski”, nr 23, 17.01.1995, s. 7; Euro - junior na naszym Rynku, „Gazeta Pleszewska”, 3.07.2012, s. 19; U. Habrych, Rekreacja z Bogusławskim, „Na skraju Gazeta Mieszkańców Podolan i Strzeszyna”, nr 2, kwiecień 2006, s. 3; U. Habrych, J. Nowak, J. Krajewski, Kolejne sukcesy pakosławskiego Ju-jitsu, „Pakosław i okolice”, nr 42, lipiec-sierpień 1999, s. 12; Koncerty, zabawy, pokazy siłaczy $i$ nie tylko, czyli Dni Obrzycka 2012, „Dzień Szamotulski”, 6.07.2012, s. 10; Kopaty z gracja, „Gazeta Kościańska”, nr 22, 31.05.2006, s. 24; Kozienice czekaja, „Gazeta Kościańska”, nr 23, 7.06.2006, s. 24; Lekkoatletyczny miting, „Panorama Leszczyńska”, nr 22, 31.05-5.06.2012, s. 44; Lipiec z GOK-em, „Życie Gostynia”, nr 28, 14.07.2000; Medale przyjechaty z Leszna, „Przegląd Koniński”, 3.07.2012, s. 30; Mosińskie Euro czas zaczać, „Gazeta Mosińsko-Puszczykowska”, nr 5, maj 2012, s. 24; Mistrzostwa Góry w biegach przełajowych, „Przegląd Górowski”, nr 6, 28.06-26.07.2012, s. 16; Mocni gospodarze, „Panorama Leszczyńska”, nr 17/18, 26.04-9.05.2012, s. 55; Na obozie sportowym, „Witryna Śmigielska”, nr 8, wrzesień 2001; Okragłe 30 lat, „Kurier Lokalny”, nr 14, 2000, s. 14-16; Najważniejsze imprezy sportowe w Wielkopolsce w 1999 r., „Merkuriusz 
ska”, odbyły się „Mistrzostwa Wielkopolski w Żonglerce Piłkarskiej [...], w kategorii kobiet - zwyciężyła Agata Ławniczak"53. Kobiety odnosiły sukcesy w wielu dyscyplinach. W 1998 roku „Rydzyna Tu i Teraz” zamieściła informację, iż „kolejny finał Wojewódzkich Igrzysk Młodzieży Szkolnej rozegrano na stadionie w Rawiczu" i w ramach zawodów z lekkoatletyki srebrny medal za rzut piłeczką palantową otrzymała Angela Wojteczek ${ }^{54}$. W „Życiu Rawicza” w 2001 r. można przeczytać o sukcesach kobiet - młodzików i juniorek rawickiego „Kadeta" w zawodach lekkoatletyki, odbywających się na stadionie Towarzystwa Sportowego „Olimpia” w Poznaniu ${ }^{55}$. Wśród młodzieży szkolnej zainteresowaniem cieszą się również szachy. W tej dyscyplinie, jak podaje „Elita” w 1999 r. rywalizowało w SP nr 6 w Kościanie 84 uczniów ze szkół podstawowych, a w finale najlepszą wśród dziewcząt okazała się Agnieszka Rutkowska ze Szkoły Podstawowej nr 8 w Lesznie ${ }^{56}$. Kobiety regionu leszczyńskiego odnoszą sukcesy również w kręglarstwie, a zrzeszone są w klubie „Polonia Leszno”. W 2005 r. „Panorama Lesz-

Leszczyński”, nr 2, luty 1999, s. 47; II Otwarty Turniej Halowy Piłki Siatkowej, „Nasze Jutro”, nr 93, luty 1998, s. 34; Pitka kopana rodzaju żeńskiego, „Nasze Jutro”, nr 93, luty 1998, s. 25; Pojadq na Olimpiade, „ABC”, nr 51, 3.07-5.07.2012, s. 21; E. Parus, zakończenie roku szkolnego u Kostaneckich, „Gazeta Słupecka”, 3.07.2012, s. 16; Powtórki finatu nie było, „Gazeta Kościańska”, nr 21, 24.05.2006, s. 30; Sukces Sławskich Judoków, „Słowo Ziemi Wschowskiej”, nr 12, 17.12.2010, s. 13; Strzelanie, „Pakosław i okolice”, nr 50, 51, Lato 2000, s. 14; Szkolna rywalizacja, „Gazeta Kościańska”, nr 47, 23.11.2005, s. 28; Siatka w „,dwójce”, „Wiadomości Kościańskie”, nr 12, grudzień 1997, s. 58; Sportowy festyn, „Życie Rawicza”, nr 37, 14.09.2001, s. 22; J. Świerkowski, Dni Gminy Suchy Las 2006, „Na skraju Gazeta Mieszkańców Podolan i Strzeszyna”, nr 3, maj 2006, s. 5; W. Urbańczak, Festyn Podolański, „Na skraju Gazeta Mieszkańców Podolan i Strzeszyna”, nr 3, maj 2006, s. 4; M. Sibilak, Sportowy festyn, „Życie Rawicza”, nr 37, 14.09.2001, s. 22; Wysoka poprzeczka, „Gazeta Kościańska”, nr 49, 7.12.2005, s. 30; W Lesznie na trzecim, „Gazeta Kościańska”, nr 26, 27.06.2012, s. 32; Zadebiutowały w lidze młodziczek, „Zw.pl”, nr 11, 2011, s. 13; Zawody w JU-JITSU, „Ziemia Wschowska”, nr 1, 10.01.2001, s. 14; http://faktypilskie.pl/index.php?option=com_content\&view=article\&id=10637:roksana-oso-mistrzyni-polski\&catid=40:sport\&Itemid $=53$, 13.07.2012.

${ }^{53}$ I. Szczepaniak, III Bajkolandia z Olimpijczykami, „Gazeta Mosińsko-Puszczykowska", nr 6, czerwiec 2012, s. 24.

${ }^{54}$ Lekkoatletyka, „Rydzyna Tu i Teraz”, nr 3, czerwiec-lipiec 1998, s. 10.

55 Pracowali nad forma, ibidem; Imprezy kulturalne, sportowe i rekreacyjne w Rawiczu i powiecie rawickim, „Gazeta Rawicka”, nr 8, sierpień 2001, s. 25.

${ }_{56}$ K. Tarka, Szachy, „Elita. Magazyn regionalny. Wiadomości ze Wschowy, Leszna i Głogowa", nr 2, luty 1999, s. 35. 
czyńska” informowała, iż ,[...] w wyjazdowym spotkaniu [...] Polonia umocniła się na prowadzeniu w ekstralidze" ${ }^{, 57}$. Z kolei pilski „Tygodnik Nowy” donosił w 2012 r., iż z regionu północnej Wielkopolski, podczas odbywającej się w Bochni Ogólnopolskiej Olimpiady Młodzieży w judo, reprezentantka Gwardii Piła Alicja Kotowska wywalczyła brązowy me$\mathrm{dal}^{58}$. Podobnie w regionie pilskim, dużym zainteresowaniem cieszy się siatkówka kobiet - ,[...] na obozie młodzieży pilskiego PTPS w Chojnicach trenowało ponad 50 dziewczyn" ${ }^{\text {"59 }}$. Natomiast w 2012 roku brązowy medal w Mistrzostwach Europy Karate Fudokan - Shotokan w Spale wywalczyła Natalia Nowak, zawodniczka Uczniowskiego Klubu Sportowego „OSiR Kleczew” ${ }^{60}$. Inne dyscypliny, które cieszą się zainteresowaniem kobiet w ostatnich kilku latach, to trójbój siłowy i taekwondo ${ }^{61}$. Prasa informowała, iż w XIX Mistrzostwach Polski Juniorek i Juniorów do lat 20 i 23 w Trójboju Siłowym w Białymstoku, złotymi medalistkami w 2008 r. zostały - Karolina Pogorzelska i Wioleta Szymkowiak ${ }^{62}$. Z kolei w 2006 r. w mistrzostwach Polski seniorów, w olimpijskiej odmianie taekwondo WTF w Puławach, dwie reprezentantki „Sokoła” - Natalia Rybarczyk wywalczyła złoto, a Katarzyna Kubacka - srebro $^{63}$. Natomiast w 2010 r. w dzienniku „ABC” opublikowano wiadomość, iż po raz dziesiąty w Jarocinie odbyły się zawody w taekwondo olimpijskim, pod nazwą „Wesołek Cup”, a uczestniczyli w nim reprezentanci „UKS Dragon” Długie Stare, „Gorwa Team Leszno” i „Sfinks Rydzyna"64. Podczas tego spotkania m.in. Agnieszka Kaczmarek wywalczyła złoto $\mathrm{w}$ walce sportowej i srebro w konkurencji sprawnościowej. Z kolei w 2012 roku brązowy medal wywalczyła w mistrzostwach Polski juniorów w taekwondo olimpijskim w Bornem Sulinowie - Dominika Szynkowska (do 59 kg, „Sokół Kościan”), o której można było przeczytać

57 Obie na czele tabeli, „Panorama Leszczyńska”, nr 49, 8.12-14.12.2005, s. 33.

$58 \mathrm{http}: / / d z i e n n i k n o w y . p l / a k t u a l n o s c i / p o k a z / 23501 . d h t m l, 13.07 .2012$.

59 Tygodnik Nowy w Chojnicach. Na Kaszubach też jest pięknie, http://www.sportowydzienniknowy.pl/news/Tygodnik-Nowy-w-Chojnicach-Na-Kaszubach-tez-jest-pieknie/24,44,1.html, 13.07.2012.

60 Wsaniaty powrót Natalii, „Przegląd Koniński”, 19.06.2012, s. 30.

${ }^{61}$ Złotka z Kościana, „Gazeta Kościańska”, nr 15, 9.04.2008, s. 28; Będa nominacje; Piętnastu z czarnym pasem, „Panorama Leszczyńska”, nr 17/18, 26.04-9.05.2012, s. 55.

62 „Gazeta Kościańska”, nr 15, 9.04.2008, s. 28.

63 "Sokót na szczytach, „Gazeta Kościańska”, nr 37, 12.09.2007, s. 28.

64 Wesolek Cup, „ABC”, nr 103, 30.12.2010, s. 31. 
- ,[...] walki wygrała po ciężkich bojach [...] dzięki temu zdobyła swój pierwszy medal na tak poważnych mistrzostwach"65. Podobnie w Puławach, Małgorzata Litwin, zawodniczka „Sokoła Kościan” wywalczyła brązowy medal finałów młodzieżowych mistrzostw polski (do lat 21) $\mathrm{w}$ taekwondo olimpijskim ${ }^{66}$. Inną dyscypliną prezentowaną na łamach prasy lokalnej jest kickboxing. W 2012 r. odbyły się w Lesznie mistrzostwa Polski w kickboxingu, podczas których ,[...] licznie reprezentowani byli w nich gospodarze - zawodniczki i zawodnicy Polonii 1912 Astromal Leszno" "67. Popularne są też zawody konne - czynne zainteresowanie tym sportem, jak donosi prasa - trwa do późnego wieku ${ }^{68}$. $\mathrm{W}$ tej dyscyplinie, kobiety zostają sędziami głównymi (np. Izabela Bek-Kaczkowska w 2012 r. we wszechstronnym konkursie konia wierzchowego, podczas krajowych zawodów w Racocie) ${ }^{69}$. Dosyć osobliwe $\mathrm{w}$ ramach dyscypliny hipicznej jest powożenie bryczkami - tutaj również swój udział mają kobiety (XXI Zawody w Powożeniu Zaprzęgami Parokonnymi im. Józefa Lipowego w Bukówcu Górnym) ${ }^{70}$. Media lokalne tak podsumowały to wydarzenie - ,wiele braw zebrała Dominika Rimke z Brenna za pozakonkursowy pokaz powożenia czterokonnym zaprzęgiem kucy"71.

Zainteresowaniem w gminach cieszą się również zawody Ochotniczych Straży Pożarnych, w których biorą udział zastępy kobiece (dwie kategorie wiekowe chłopców i dziewcząt - od 12 do15 lat i od 16 do 18 lat $)^{72}$. „Gazeta Górowska” ukazująca się na terenie woj. dolnośląskiego, graniczącego z Wielkopolską zamieściła informację, iż „26 sierpnia spotkali się na boisku sportowym w Boguszynie strażacy ochotnicy z terenu gminy Włoszakowice [Wielkopolska - od aut.]", publikując również zdjęcie zwycięskiej drużyny seniorek (16-18 lat) OSP Dłużyna ${ }^{73}$.

65 Brqz w debiucie, „Gazeta Kościańska”, nr 26, 27.06.2012, s. 32.

66 Brqz dla Litwin, „Gazeta Kościańska”, nr 27, 4.07.2012, s. 31.

67 O krajowy prymat, „ABC”, nr 44, 08.06-11.06.2012, s. 31.

68 Grand Prix dla Marka Ortosia, „Gazeta Kościańska”, nr 23, 7.06.2006, s. 31; Dla młodych jeźdźców i koni, „Panorama Leszczyńska”, nr 21, 24.05-30.05.2012, s. 7.

69 Konkurs wszechstronny, „Panorama Leszczyńska”, nr 20, 17.05-23.05.2012, s. 46.

70 Panie też powoża, „Panorama Leszczyńska”, nr 19, 10.05-16.05.2012, s. 46.

71 Ibidem.

72 Strażacy na sportowo, „Wiadomości Miejskogóreckie”, nr 3/4 (54/55), maj-czerwiec/lipiec-sierpień 2001, s. 6.

73 Sportowe zmagania strażaków ochotników, „Gazeta Górowska”, nr 15, 10.09.2001, s. 11 . 
Międzynarodowe sukcesy kobiet są także odnotowane na łamach prasy lokalnej. W 1999 roku młodzi pływacy KP „Akwawit” (sześć kobiet i sześciu mężczyzn) brali udział w zawodach pływackich, w Gelsenkirchen (Niemcy) i zajęli szóste miejsce ${ }^{74}$. W 2005 roku „Witryna Śmigielska” zamieszcza wiadomość, iż „w Cottbus (Niemcy) odbył się coroczny Europa Sport Festival [...] młodzi sportowcy zmagali się w różnych dyscyplinach, m.in. w turnieju szachowym [...] najlepszymi zawodnikami naszej ekipy byli Małgorzata Łupicka i Mateusz Górny, otrzymując 5 pkt. ${ }^{, 75} \mathrm{~W}$ tym samym roku, Leszno było organizatorem szermierczego Pucharu Świata w kategorii juniorów, podczas którego „[...] startowało 60 juniorek z 11 państw"76. W 2011 roku można dowiedzieć się o „kolarce” odnoszącej sukcesy we Włoszech ${ }^{77}$. Prasa lokalna informuje również, iż w 2012 roku na Ukrainie, w Mariupolu odbyły się Mistrzostwa Europy Seniorów w Trójboju Siłowym, podczas których startowały Agata Sędziak (5 miejsce) i Kamila Kasperska (4 miejsce) z „Kobra Jass Kościan”78. W tej samej dyscyplinie w 2012 roku mieszkańcy powiatu wschowskiego Marzena Piter i Krzysztof Wierzbicki (MOSiR Mikołów) wrócili ze Szwecji z Pucharu Świata seniorów z medalami w kategorii open: złotem i srebrem ${ }^{79}$. Zwycięstwem też może poszczycić się judoczka Paula Kułaga z TDK Judo Trzcianka, która w 2012 roku w Czarnogórze, w miejscowości Bar zdobyła brązowy medal Mistrzostw Europy w kategorii juniora młodszego ${ }^{80}$.

Jednak znaczącym sukcesem w regionie w ostatnich latach, stało się m.in. powołanie w 2008 roku trzech koszykarek Dudy do reprezentacji Polski - Darii Mieloszyńskiej, Maryny Koc i Edyty Krysiewicz, które miały szansę wziąc udział w meczach eliminacyjnych mistrzostw Euro$\mathrm{py}^{81}$. W kadrze narodowej seniorek w pływaniu synchronicznym są lesz-

74 K. Tarka, Pływanie. Grad złota, „Elita Magazyn regionalny. Wiadomości ze Wschowy, Leszna i Głogowa”, nr 2, luty 1999, s. 35.

75 Sukcesy „,Wieży”, „Witryna Śmigielska”, listopad 2005, s. 18.

76 Dziura w roczniku, „Panorama Leszczyńska”, nr 49, 8.12-14.12.2005, s. 33.

77 Kolarki we Włoszech, „Panorama Leszczyńska”, nr 29, 21.07-27.07.2011, s. 38.

78 R. Szymkowiak, Agata i Kamila na Ukrainie, „Kurier Lokalny”, nr 11, 28.05.2012, s. 9.

79 Trops nie przetrwal - zawodnicy tak, „Panorama Leszczyńska”, nr 28, 12.07-18.07.2012, s. 39.

80 M. Markowski, Paula blisko finału, „Tygodnik Nowy”, 7.03.2012, s. A33.

81 Dziewczyny maja wzięcie, „Panorama Leszczyńska”, nr 17, 24.04-29.04.2008, S. 45 . 
czynianki - Roberta Klecz i Zuzanna Frydrych (wicemistrzynie Polski juniorek i brązowe medalistki wśród seniorek $)^{82}$. Podobnie prasa lokalna w 2012 roku i wcześniejszych latach opisuje spektakularne zwycięstwa dwóch kobiet z regionu leszczyńskiego - Anity Włodarczyk w rzucie młotem (m.in. w 2008 r. na Igrzyskach Olimpijskich w Pekinie zajęła 6 miejsce z wynikiem 71,56 m) i Agnieszki Jerzyk w triathlonie (m.in. w kwietniu 2012 r. zajęła 6 miejsce w Mistrzostwach Europy). Obie panie reprezentowały Polskę podczas XXX Igrzysk Olimpijskich w Londynie $^{83}$. Warto dodać, że w roli chorążego Reprezentacji Polski podczas otwarcia tych Igrzysk 27 lipca 2012 roku była tenisistka Agnieszka Radwańska. Jest ona zarazem pierwszą kobietą $\mathrm{w}$ historii wypełniająca tę rolę z ramienia Polski w letnich Igrzyskach Olimpijskich ${ }^{84}$. Na 222 proponowanych zawodników w 22 dyscyplinach, w Igrzyskach będzie brało udział 90 kobiet, jak wówczas donosiły media ${ }^{85}$. Niektóre dyscypliny były reprezentowane tylko przez kobiety, np. w boksie - Karolina Michalczuk (PACO Lublin) oraz w strzelectwie, zawodniczki: Sylwia Bogacka (ZKS Gwardia Zielona Góra), Agnieszka Nagay (WKS Orzeł Łódź), Beata Bartków-Kwiatkowska (TS Wisła Kraków) i Paula Wrońska (Lider-Amicus Lębork) ${ }^{86}$. Natomiast nie było kobiet w taekwondo. Z Wielkopolski na Igrzyska do Londynu zakwalifikowano dwudziestu zawodników, w tym jedenaście kobiet z następujących dyscyplin: lekkoatletyka - Żaneta Glanc (AZS Poznań, rzut dyskiem), Joanna Fiodorow (AZS Poznań, rzut młotem) i Patrycja Wyciszkiewicz (Olimpia Poznań, sztafeta 4x400 m); kajakarstwo - Aneta Konieczna (Warta Poznań, K -1500 m i K -4500 m) i Marta Walczykiewicz (KTW Kalisz, K - 1200 m, K - 4500 m); wioślarstwo - Julia Michalska (Tryton Poznań, dwójka podwójna) i Natalia Madaj (Posnania, czwórka podwójna); szermierka - Małgorzata Wojtkowiak (AZS AWF Poznań, floret drużynowy) i Martyna Synoradzka (AZS AWF Poznań, floret drużynowy); kolarstwo szosowe - Katarzyna Pawłowska (Limaro Kórnik) oraz tria-

82 Czuja się jak ryby w wodzie, „Panorama Leszczyńska”, nr 28, 12.07-18.07.2012, s. 37 .

83 Wojtasiewicz jeszcze czeka, „Panorama Leszczyńska”, $\operatorname{nr} 26,28.06-$ 4.07.2012, s. 39; Anita najlepsza w Europie, „ABC”, nr 51, 3.07-05.07.2012, s. 1 i 22 .

84 www.pkol.pl/ pages/news/5143, 13.07.2012.

85 http://olimpijski.pl/pl/files/Download/Sklad_v3_10_07_2012.pdf, 13.07.2012.

86 Ibidem. 
thlon - Agnieszka Jerzyk (64-sto Leszno) ${ }^{87}$. W tej grupie nie została ujęta Anita Włodarczyk, gdyż obecnie reprezentuje Mazowsze (RKS Skra Warszawa, wcześniej AZS AWF Poznań, Kadet Rawicz). Anita Włodarczyk spełniła oczekiwania polskich kibiców i jak można było przeczytać miesiąc później - „[...] sięgnęła po srebrny medal" ${ }^{\prime 8}$, rzucając młotem na odległość $77,60 \mathrm{~m}$ oraz ,[...] w wywiadzie dla telewizji Włodarczyk dziękowała swoim najbliższym i wszystkim kibicom z Rawicza. Medal dedykowała zmarłej przed trzema laty lekkoatletce, Kamili Skolimowskiej" "89. Media wielkopolskie szczególnie kibicowały kajakarkom, wioślarkom i kolarkom ${ }^{90}$. I nie zawiodła ich oraz kibiców para wioślarek - Magdalena Fularczyk (RTW LOTTO - Bydgostia - WSG Bydgoszcz) i Julia Michalska (Tryton Poznań), które zdobyły brązowy medal w dwójce podwójnej ${ }^{91}$. Polki na Igrzyskach w Londynie zdobyły 5 medali olimpijskich. Oprócz już wymienionych kobiet srebrny medal otrzymała również Sylwia Bogacka (strzelectwo, karabinek pneumatyczny) oraz brązowe - Zofia Noceti-Klepacka (żeglarstwo, klasa RS:X), oraz Beata Mikołajczyk i Karolina Naja (kajakarstwo, dwójka na 500 m) ${ }^{92}$. Prasa lokalna również w 2012 roku była świadkiem pożegnania olimpijki z Aten (wielokrotnej medalistki mistrzostw Polski) - lekkoatletki Liliany Zagackiej (LKLA Krokus Leszno), która po 18 latach zakończyła karierę sportową podczas zawodów lekkoatletycznych o Grand Prix Leszna $^{93}$. Do grupy wybitnych sportowców kobiet, związanych przez lata z klubami sportowymi w Wielkopolsce należały również siatkarki - Beata Strządała, Agnieszka Kosmatka oraz Milena Sadurek-Mikołajczyk $^{94}$. Ta druga na zakończenie swojej 14-letniej kariery w 2012 roku,

87 http://www.wielkopolskisport.pl/poznan-informacje,9373,Dwudziestka-na-Londyn.html, 13.07.2012; http://www.gloswielkopolski.pl/artykul/612215, 13.07.2012.

$88 \mathrm{http}: / /$ elka.pl/content/view/59234/81/, 13.08.2012.

$89 \mathrm{http}: / /$ elka.pl/content/view/59202/137/, 10.08.2012.

90 Aleksandra Dawidowicz jedzie do Londynu, „Życie Kalisza”, 20.06.2012,

s. 36; L. Gracz, Kalendarz kibica, „IKS”, 1.08.2012, s. 82.

$91 \mathrm{http}: / /$ poznan.gazeta.pl/poznan/51,36039,12324746.html?i=4, 19.08.2012.

92 http://www.pkol.pl/pl/pages/news/5555, 12.08.2012.

93 Pożegnanie olimpijki, „Panorama Leszczyńska”, nr 24, 14.06-20.06.2012, s. 46.

94 www.wielkopolskisport.pl/sportowiec,21,Agnieszka-Kosmatka.html, 13.07.2012; www.wielkopolskisport.pl/sportowiec,24,Beata-Strzadala.html, 13.07.2012; www.wielkopolskisport.pl/sportowiec,9,Milena-Sadurek.html, 13.07.2012. 
została przez pilskie media nazwana ikonq PTPS- $u^{95}$ i od tej pory występuje $\mathrm{w}$ roli menadżera drużyny ${ }^{96}$.

W prasie lokalnej zamieszczono również cykl artykułów prezentujących partnerów życiowych sportowców z regionu południowo-zachodniej Wielkopolski. Bohaterami tych reportaży są z reguły panie - żony i narzeczone, a sportowcami - mężczyźni ${ }^{97}$. Nie można jednak zapomnieć o kobietach - trenerkach i organizatorkach wydarzeń sportowych. Jak donosi „Witryna Śmigielska” „[...] po raz siódmy już odbył się [...] minitriathlon [...], organizatorem była Rada Sportu oraz Centrum Kultury" (reprezentowani przez trzech mężczyzn i jedną kobietę - Danutę Strzelczyk) ${ }^{98}$. Zainteresowanie dyscypliną sportową (powszechną czy olimpijską) może być wyrażana poprzez plebiscyty najpopularniejszych sportowców i trenerów. W 2005 r. wśród kobiet w regionie leszczyńskim znalazły się - Cecylia Pudlicka (Polonia Leszno; boks, kickboxing), Liliana Zagacka (Krokus Leszno; lekkoatletyka), Magdalena Wawrzyniak (Satori Leszno; karate) ${ }^{99}$. Niestety typowania ekspertów w kategorii najpopularniejszy trener, nie uwzględniły kobiet, podobnie jak w latach późniejszych. Natomiast już w 2010 roku na łamach „Panoramy Leszczyńskiej” eksperci typują w XXXII plebiscycie na najpopularniejszych sportowców i trenerów na drugim miejscu Anitę Włodarczyk, zaraz po Jarosławie Hampelu (Unia Leszno) ${ }^{100}$. W 2012 roku prasa lokalna stwierdza - to „najlepsza polska młociarka”"101. Natomiast w wielkopolskich mediach elektronicznych pojawiają się komentarze - „Włodarczyk królową Starego Kontynentu" z wynikiem 74,29 metrów ${ }^{102}$. Tym bardziej zwycięstwo to jest istotne, gdyż złoto w lekkiej atletyce na

95 http://www.sportowefakty.pl/siatkowka/289515/po-14-latach-w-pile-ikona-ptps-u-konczy-kariere, 13.07.2012.

96 http://www.gloswielkopolski.pl/artykul/594805,ptps-ma-juz-spolke-a-bedzie-mial-argentynke,id,t.html, 13.07.2012.

97 K. Bodzińska, Optymistka i ryzykantka, „Panorama Leszczyńska”, nr 34, 25.08-31.08.2011, s. 40; K. Bodzińska, Rozstania nie tylko dziela, „Panorama Leszczyńska", nr 33, 18.08-24.08.2011, s. 40.

98 Od najmłodszych po najstarszych, od plywania po bieg, „Witryna Śmigielska”, nr 8, wrzesień 2001, s. 17.

99 Typuja eksperci, „Panorama Leszczyńska”, nr 49, 8.12-14.12.2005, s. 33.

100 Kto zwycięży?, „Panorama Leszczyńska”, nr 51, 23.12-29.12.2010, s. 52.

101 Nasza złota Anita, „Panorama Leszczyńska”, nr 27, 5.07-11.07.2012, s. 38.

102 www.pkol.pl/plpages/news/5134, 13.07.2012; http://elka.pl/content/view/58551/137/, 13.07.2012. 
tym poziomie wywalczyła 30 lat temu Lucyna Linger (100 m przez płotki) ${ }^{103}$. Z kolei w regionie pilskim w 2010 roku najpopularniejszym sportowcem wśród kobiet w plebiscycie „Tygodnika Pilskiego” z lokatą na czwartym miejscu była wioślarka Anna Karzyńska (Orzeł Wałcz), a sportowym talentem judoczka Katarzyna Wiszniewska (UKS „6" Piła $)^{104}$. Ta ostatnia rok później znalazła się na czwartym miejscu kandydatów, zaraz po Darii Pająk, zawodniczce bowlingu (KB Rodło Piła), a zwycięzcą wśród kobiet na najpopularniejszego sportowca została Milena Zarańska (trzecie miejsce, strzelectwo SKS I-C Piła) ${ }^{105}$. W tym samym plebiscycie, sportowym talentem w 2011 roku została Aleksandra Kiereta (pierwsze miejsce, strzelectwo SKS I-C Piła) ${ }^{106}$. Natomiast w 2012 roku w plebiscycie „Głosu Wielkopolskiego” na Najlepszych Sportowców i Trenera Wielkopolski najlepszym sportowcem 2011 roku niezmiennie od 2010 roku został żużlowiec Jarosław Hampel (Unia Leszno), na pozycji drugiej - kajakarka Marta Walczykiewicz (KTW Kalisz), trzeciej - Żaneta Glanc (lekka atletyka AZS Poznań), a czwartej - Agnieszka Jerzyk (triathlon, Real 64-sto Leszno) ${ }^{107}$. Warto dodać, że w tych eliminacjach w 2009 roku wygrała Anita Włodarczyk, a od pierwszego plebiscytu, który miał miejsce w 1958 r. do 2011 roku zwyciężyło 10 kobiet (1967 - Daniela Jaworska - lekka atletyka; 1975 - Adela Dankowska - szybownictwo; 1997 - Izabela Dylewska-Światowiak/Elżbieta Urbańczyk - kajakarstwo; 1998 - Elżbieta Kuncewicz/Ilona Mokronowska - wioślarstwo; 2002, 2004, 2008 - Aneta Konieczna - kajakarstwo; 2003 - Katarzyna Skowrońska - siatkówka; 2005 - Izabela Bełcik - siatkówka; 2009 - Anita Włodarczyk - lekka atletyka) ${ }^{108}$.

Kobiety na łamach prasy chętnie wypowiadają się na temat swoich zainteresowań - wśród których wymienić można nie tylko pasje sportowe, ale też podróże, grę na instrumentach czy też kolekcjonowanie

103 Ibidem.

104 www.pilskisport.pl, 13.07.2012.

105 http://pila.naszemiasto.pl/artykul/1232703,plebiscyt-tygodnika-pilskiego-wybieramy-10,id,t.html, 13.07.2012; http://pila.naszemiasto.pl/artykul/galeria/1320047,10-najpopularniejszych-sportowcow-regionu-pilskiego,id,t.html, 13.07.2012.

106 Ibidem.

107 http://www.gloswielkopolski.pl/artykul/501198,jaroslaw-hampel-najlepszym-sportowcem-wielkopolski,id,t.html, 13.07.2012; http://elka.pl/content/view/54964/133/, 13.07.2012.

108 http://epoznan.pl/sport-news-30407-Hampel_najlepszym_sportowcem_Wielkopolski, 13.07.2012. 
książek na określony temat ${ }^{109}$. Niektóre $\mathrm{z}$ nich działają w stowarzyszeniach, inne - upubliczniają swój dorobek, np. tworząc tak jak Urszula Dominiak Galerię Sztuki Afrykańskiej ${ }^{110}$. Coraz częściej też wzorem staje się kobieta wysportowana, silna charakterem, która będzie lepiej znosić przeciwności losu. Stąd też pojawiły się informacje na temat racjonalnego odżywiania oraz zdrowego stylu życia i pielęgnowania urody, niejednokrotnie powiązane ze sportową pasją kobiet ${ }^{111}$.

109 E. Przybyłek, To moja pasja i radość, „Gazeta Wschowska”, nr 10 (47), 1998, s. 12; M. Śliwka, Kubistyczne dziwactwa, „Wiadomości Kościańskie”, nr 1 (123), styczeń 1999, s. 47; Artyści tworza też noca, „Wiadomości Kościańskie”, nr 6 (116), czerwiec 1998, s. 19.

110 A. Andrejów, W rytmie afrykańskich tam-tamów, „Elita”, nr 1 (1), listopad 1998, s. 8.

111 K. Bodzińska, Calineczka z dobrym gustem, „Panorama Leszczyńska”, nr 22, 2.06-8.06.2011, s. 23; Czy depresję można lekceważyć, „Gazeta Górowska”, nr 15 (91), 10 października 2001, s. 5; Ćwicz z Arkiem, „Panorama Leszczyńska”, nr 24, 14.06-20.06.2012, s. 40; Dotyka co siódma kobietę, „Panorama Leszczyńska”, nr 11, 17.03-23.03.2011, s. 26; Dwa tytuly dla Szakiry, „Panorama Leszczyńska”, nr 12, 24.03-30.03.2011, s. 24-25; Dziedziczyć ma ta, która kochat, „Panorama Leszczyńska”, nr 21, 26.05-2.06.2011, s. 11; Dziewczyny czekaja na szczepienia, „Panorama Leszczyńska”, nr 32, 11.08-17.08.2011, s. 5; „Głos Lipna”, nr 2, 2001, s. 11; Intymna strona kobiety, „Panorama Leszczyńska”, nr 32, 11.08-17.08.2011, s. 22; A. Krall-Świetlik, Kolorowo $i$ z dodatkami, „Panorama Leszczyńska”, nr 32, 11.08-17.08.2011, s. 23; A. Krall-Świetlik, Mniej znaczy lepiej, „Panorama Leszczyńska", nr 33, 18.08-24.08.2011, s. 23; A. Krall-Świetlik, Rzymianki? Koniecznie!, „Panorama Leszczyńska”, nr 31, 4.08-10.08.2011, s. 21; A. Krall-Świetlik, Trencz - hit sezonu, „Panorama Leszczyńska”, nr 13, 31.03-6.04.2011, s. 23; Kosmetyczka radzi, „Kurier Lokalny”, nr 18 (251), 2001, s. 7; A. Maćkowiak, Odżywiaj się z glowa, „Panorama Leszczyńska”, nr 16, 21.04-27.04.2011, s. 34; E. Matyśkiewicz, Problem na głowie, „Wiadomości Kościańskie”, nr 12 (122), grudzień 1998, s. 66; Nie zbieraj grzybów na basenie!, „Panorama Leszczyńska”, nr 33, 18.08-24.08.2011, s. 22; Nowe oferty gabinetu „Ewa”, „Gazeta Wschowska”, nr 10 (47), 1998, s. 6; Nasze miss od parowozów, „Panorama Leszczyńska”, nr 33, 18.08-24.08.2011, s. 25; One chcq być miss, „Panorama Leszczyńska”, nr 6, 10.02-16.02.2011, s. 26-27; E. Olsza, Być wegetarianka, „Wiadomości Jutrosińskie”, nr 71, 1999, s. 6; Piękne dziewczyny, zabytkowe maszyny, „Panorama Leszczyńska”, nr 33, 18.08-24.08.2011, s. 2; I. Radwan, Czy zima urodzie sprzyja?, „Merkuriusz Leszczyński”, nr 2 (9), 1999, s. 55; I. Radwan, Kolorowy zawrót głowy, „Merkuriusz Leszczyński”, nr 3-4, marzec-kwiecień 2000, s. 49; E. Sobańska, Ty też jesteś piłkarska wdowa?, „Głos Wielkopolski”, 9.06.2012, s. 8; S. Świtalska, To nie igraszki to rok!, „Gazeta Gostyńska”, nr 14, 14 lipca 2000, s. 4; A. Szklarska-Meller, Piękna w kilka chwil, „Panorama Leszczyńska”, nr 21, 26.05-2.06. 2011, s. 22; Sztuka suszenia, „Panorama Leszczyńska”, nr 16, 
Trzeci etap badań, pokazał inny wymiar kobiecości w kontekście sportowych fascynacji. Opierając się wyłącznie o część badań prowadzonych przez autorkę od 1 czerwca do 16 lipca w prasie lokalnej objętej monitoringiem tytułów regionalnych i lokalnych Wielkopolski, można stwierdzić, że na 1499 informacji nawiązujących do Mistrzostw Europy w Piłce Nożnej 2012 (aktywność w tym temacie przejawiło 39 tytułów, głównie dzienników i tygodników), jedna na 20 - dotyczyła kobiet. Wizerunek ten $\mathrm{w}$ pierwszej kolejności odnosi się do kobiety kibica (styl prezentowania się podczas mistrzostw, kibicowanie $\mathrm{w}$ grupie rodziny i znajomych), a w drugiej - kobiety pięknej (np. informacje nawiązywały do żon i partnerek piłkarzy zasiadających na trybunach, zdjęcia fanek wielu narodowości i policjantek oraz wybrano polską miss Euro 2012 - Natalię Siwiec) $)^{112}$. Trzecim wątkiem dominującym jest prezentowanie sportowych osiąnnięć kobiet w kontekście Euro 2012 ${ }^{113}$. Kobieta

21.04-27.04.2011, s. 32; Wybory Miss Miasta i Gminy Kobylina, „Kobylin. Pismo Samorządu Miasta i Gminy", listopad-grudzień 1998, s. 13.

112 A. Jasińska, Irlandzcy kibice w Poznaniu pokochali paniq posterunkowq, „Głos Wielkopolski”, magazyn, 29.06.2012, s. 6; Kasia utrwalata kibiców, „ABC”, 29.06.2012, s. 14; M. Kaczmarek, Co robity panie podczas Euro...?, „Przegląd Koniński”, 7.03.2012, s. 39; Kibicuj rodzinie, „Przewodnik Katolicki”, 17.06.2012, s. 10; K. Koziołek, Jak mieszkanka Leszna zarabia na filmach w sieci, „Głos Wielkopolski”, 30.06.2012, s. 7; Ł. M. Kurczak, Klikaj na kibitke, „Echo Miasta”, Poznań, 21.06.2012, s. 2; Mała Nadia wierna fanka!, „Tygodnik Wagrowiecki”, 6.07.2012, s. 11; Mistrzowskie wspomnienia, „Monitor Wielkopolski”, 1.07.2012, s. 6; My biato-czerwoni, „ABC”, $\mathrm{nr} 45,12.06-14.06 .2012$, s. 1, Jak kibicowaliśmy Polsce podczas meczu z Grecja, „ABC”, nr 45, 12.06-14.06.2012, s. 14; Nie ma Euro bez żon i dziewczyn, „Głos Wielkopolski”, Dodatek 1, 18.06.2012, s. 4; M. Nicpoń, Kilkanaście tysięcy osób bawito się w pilskiej strefie kibica, „Tygodnik Pilski”, 3.07.2012, s. 9; Paznokcie w barwach narodowych na Euro!, „Głos Wielkopolski”, 9.06.2012, s. 2; Sz. Pewiński, To byly niezwykłe trzy tygodnie, „Dzień Wolsztyński”, 3.07.2012, s. 8; „Zw.pl”, nr 5, 2012, s. 1; Piękniejsza strona mistrzostw, „Głos Wielkopolski”, Dodatek, 25.06.2012, s. 5; Strefa Kibica w Nowym Dworze, „Tygodnik Nowy”, 26.06.2012, s. 17; EUROnotki, „Panorama Leszczyńska”, nr 23, 6.0613.06.2012, s. 25; A. Krall-Świetlik, Sportowy piłkoszat, „Panorama Leszczyńska”, nr 25, 12.06-27.06.2012, s. 35; Wybrano najlepsze stroje na Euro, „Gazeta Słupecka”, 19.06.2012, s. 24; Z miłości do piłki nożnej i reprezentacji, „Echo Miasta”, Poznań, 2.07.2012.

113 A. Domański, Jest sukces nie ma basenu, „Tygodnik Śremski”, 13.07.2012, s. 19; M. Idczak, Finał marzeń turnieju piłkarzyków, „Głos Wielkopolski”, 2.07.2012, s. 5; Wielki Turniej w Piłkarzyki emocjonuje nawet panie, "Głos Wielkopolski”, 11.06.2012, s. 5; Zagraj z nami mistrzyniami, „Gazeta Wyborcza - Poznań”, 1.06.2012, s. 3. 
piękna jako sportowiec była już wcześniej zauważona w prasie lokalnej. Przykładem może być aktorka Joanna Jabłczyńska, która jest także zawodniczka, jak i twarzą grupy kolarskiej HP Sferis Racing Team (wyścigi szosowe i MTB), a dopiero w dalszym akapicie media lokalne informują o Oldze Wasiuk, tegorocznej mistrzyni Polski w kolarstwie przełajowym (mniej rozpoznawalna niż jej poprzedniczka) ${ }^{114}$. Zainteresowanie wielkopolskich mediów podczas Euro 2012 wzbudziła Natalia Kazimierczak, gimnazjalistka z Kiełczewa (gmina Kościan), która uczestniczyła $\mathrm{w}$ grupie osób podających piłkę podczas meczu Polska - Czechy (program „Adidas Ball Kids”) ${ }^{115}$. W „Panoramie Leszczyńskiej” na okładce zamieszczono zdjęcie Natalii Kazimierczak oraz m.in. informację ,[...] znalazła się w 12 osobowej grupie młodzieży [...]. Miała doskonałe miejsce za bramką. W pierwszej połowie rzucała futbolówkę Petrowi Cechowi, w drugiej Przemysławowi Tytoniowi",116. Niewatpliwie rarytasem informacyjnym w prasie lokalnej jest publikacja poświęcona pracy i sylwetce Magdaleny Szulczyńskiej pochodzącej również z Kościana, która od dwóch lat jest zatrudniona w UEFA jako asystentka Alexandre'a Fourtoya, dyrektora ds. komunikacji, i to ,„[... od nich zależało, co cały świat widział w swoich telewizorach oglądając Euro 2012" $" 117$. Swoje miejsce w historii polskiego Euro zajęła również inna kobieta. W prasie można było przeczytać - „W Poznaniu dużo mówi się o tym, że Euro 2012 jest mężczyzną. Za mistrzostwami idą męskie inwestycje: stadion, drogi... Tymczasem jedną z nich - strefą kibica kieruje kobieta, Katarzyna Parysek"118.

Autorami publikacji z zakresu tematyki kobiecej w latach dziewięćdziesiątych, jak i obecnie są w większości kobiety (dziennikarki m.in. - Irena Anna Bajserowicz, Karolina Bodzińska, Izabela Domaszewska, Hanna Hejduk, Lila Gabryelów, Barbara Głowinkowska, Agnieszka Gnat, Marta Krzyżanowska, Krystyna Konieczna, Magdalena Lorek, Ewa Noga-Mazurek, Irena Michalewicz, Angelika Pietrowiak, Elżbieta

114 Joanna Jabłczyńska - gwiazda na rowerze, „Panorama Leszczyńska”, nr 19, 10.05-16.05.2012, s. 46.

115 Podawałam piłkę Tytoniowi, „Gazeta Kościańska”, nr 26, 27.06.2012, s. 29.

116 M. Cwojda, Rzucała futbolówkę Tytoniowi, „Panorama Leszczyńska”, nr 25, 12.06-27.06.2012, s. 1.

117 A. Muenzberg-Czubała, Mieliśmy puchar przed Hiszpanami!, „Gazeta Kościańska”, nr 27, 4.06.2012, s. 16-17.

118 J. Suchęcka, Wielka Organizatorka, „Gazeta Wyborcza - Poznań”, 2.06.2012, s. 12 . 
Przybyłek, Bożena Przybylak, Beata Pona, Beata Sikora, Elżbieta Szpecht-Rutecka, Krystyna Szumna, Halina Siecińska, Aneta Włodarczak), choć kategoria sportowa opisywana była zwykle przez mężczyzn (m.in. Andrzej Bartkowiak, Jan Dwornik, Mariusz Cwojda, Rafał Makowski, Robert Lewandowski, Jerzy Wizerkaniuk) ${ }^{119}$.

Obecnie w stosunku do lat 90-tych zmieniło się położenie kobiet w różnych sferach życia - w dziedzinie oświaty, w rodzinie, na rynku pracy i w życiu publicznym, dowodzą tego nie tylko media, ale też badania prowadzone w ośrodkach naukowych ${ }^{120}$. Stąd też coraz śmielej w męskie sporty wchodzą kobiety, nie odcinając się od popularnej gimnastyki, tenisa, siatkówki, koszykówki i tańca ${ }^{121}$. Niemniej, analiza prasy lokalnej potwierdziła obserwacje wspólnot. Szerokie spektrum zainteresowania sportami dotyczy kobiet młodych (zdobywających wykształcenie), a kobiety w sile wieku (30-40 lat) i starsze - częściej uprawiaja sport rekreacyjnie, zwłaszcza takie dyscypliny jak aerobik (w różnych postaciach), jazda na rowerze i nordic walking ${ }^{122}$. Niestety prasa lokalna rzadko podejmuje temat uprawiania sportu przez osoby w średnim wieku i starsze, co nie sprzyja propagowaniu zdrowego stylu życia. Problematyka sportowa w mediach lokalnych pozwala postawić kolejne wnioski. Sporty, przyjęte za luksusowe lub mało dostępne (ze względu chociażby na infrastrukturę, środki pieniężne, popyt) występują z różną częstotliwością (często, rzadko lub wcale), w zależności od miasta i gminy. Przykładem może być miasto Poznań i Leszno. W pierwszym mieście - na łamach prasy lokalnej pojawia się np. balet, krykiet, a w drugim już nie. Dominują informacje o sportach angażujących mniejsze środki finansowe w gminach i miastach (np. tenis stołowy, lekkoatletyka, karate, taekwondo), co wynika z przyjętego pola badawczego, w którym to dominują miasta i gminy kilkunastotysięczne (większe ośrodki to głównie

119 Szerzej - E. Jurga, Dziennikarze wielkopolskiej prasy lokalnej w III RP, w: Prasa dawna i współczesna, red. B. Kosmanowa, część piąta, Poznań 2004, s. 95-106.

120 Por. Stereotypy $w$ obszarze społecznym i politycznym, red. B. Pająk-Patkowska, Poznań 2011; http://www.cpk.org.pl/images/stories/documents/attach_86.pdf, 25.06.2012; http://www.stat.gov.pl/cps/rde/xbcr/gus/Kobiety_w_Polsce.pdf, 25.06.2012.

121 Czirliderki ze Śmigla w pólfinale!, „Gazeta Kościańska”, $\mathrm{nr} 24,14.06 .2006$, s. 4; Lubuska Gala Taneczna, „Słowo Ziemi Wschowskiej”, nr 6, 15.06.2012, s. 15; Roztańczona hala Arena, „Ziemia Kaliska”, 6.07.2012, s. 2B.

122 Otwarcie trasy Nordic walking, „Przegląd Górowski”, nr 6, 28.06-26.07.2012, s. 16; http://www.zycie.pila.pl/aktywna/informacje/20120305-wiosenne-przebudzenie-otwiera-sezon-turystyczny/index.php, 13.07.2012. 
Poznań, Leszno i Piła - byłe miasta wojewódzkie w latach 1975-1998), w których to z kolei występuje wiele czynników (np. infrastruktura, środki pieniężne czy osobowe) ograniczających występowanie kategorii sportowych. Tym samym prasa lokalna określonego obszaru częściej publikuje artykuły odnośnie wyróżniającego się sportu w zasięgu swojej dystrybucji (np. w Lesznie - najczęściej żużel, koszykówka, szermierka i lekkoatletyka, w Kościanie - karate, fregaty, piłka nożna). Prasa chętniej pisze o sportach wiążących się z określonymi imprezami sportowymi, czy w szerokim kontekście - kulturalnymi albo widowiskowymi. Popularne sporty rekreacyjne (jazda na rowerze, gimnastyka, nordic walking) pojawiają się rzadko (jedna informacja na 48 egzemplarze) podczas gdy tenis czy lekkoatletyka jest niemalże w każdym numerze, a luksusowe sporty (np. jeździectwo, kajakarstwo) w sezonie wiosenno-jesiennym pojawiają się raz na 4 badane egzemplarze). Wydarzenia sportowe ważne na skalę kraju - angażują szeroko dzienniki i tygodniki (aktualność informacji przekłada się na popyt), a miesięczniki i kwartalniki z reguły podsumowują działalność lokalnych klubów i ich liderów. Prasa lokalna i regionalna w stosunku do sportowych zainteresowań kobiet pełni funkcję informacyjną (w aspekcie współczesnym i historycznym) oraz integracyjną. Jest zapisem nie tylko fragmentu życia określonej wspólnoty, ale może przyczynić się do rozszerzenia kręgu sympatyków określonej dyscypliny.

Analizując powyższą tematyką, nasuwa się również kilka uwag z zakresu ekspozycji materiałów prasowych. Prasa lokalna i regionalna Wielkopolski w tym aspekcie również wpisała się w nurt tabloidyzacji mediów. Warto zaznaczyć, iż tabloidyzacja informacji (w szerokim spektrum tematycznym) towarzyszyła mediom, począwszy od transformacji systemowej, choć jej natężenie przypada na ostatnie dziesięciolecie. I nie ma różnicy czy wydawcą jest osoba prywatna, czy instytucja. Elementy składające się na informację tabloidalną znajdują się zarówno w prasie lokalnej i regionalnej, nastawionej na szerokiego, jak i wąskiego odbiorcę (np. w pismach regionalistycznych - zwłaszcza w biografiach osób tworzących historię regionu, takie pierwiastki można dostrzec np. w „Zeszytach Osieckich”, „Przyjacielu Ludu”, „Rydzyniaku” czy „Zapiskach Grabonoskich"). Wniosek jest następujący - tabloidyzacja dotyczy wszystkich typów mediów lokalnych i regionalnych, w mniejszym lub większym stopniu, a jest warunkowana przyzwoleniem wydawcy. Ten kieruje się najczęściej względami ekonomicznymi pisma, uwzględniając układy polityczne i biznesowe w danej wspólnocie. Jednak bada- 
nia nad określonym tytułem prasy lokalnej lub regionalnej mogą w pełni odpowiedzieć, czy dane medium zasługują na miano tabloidu (zgodnie $\mathrm{z}$ definicją Colina Sparksa ${ }^{123}$ ) lub jaki procent udziału informacji tabloidalnej jest preferowany przez redakcję. Pierwsze w Polsce badania nad tabloidyzacją mediów dotyczyły porównania zawartości dwóch wiodących programów informacyjnych: „Faktów” TVN i „Wiadomości” TVP 1 (Dorota Piontek, Bartosz Hordecki) i wyniki badań potwierdziły tezę o tabloidyzacji tychże (konkurujących ze sobą) programów informacyjnych, choć zjawisko to ma różne nasilenie ${ }^{124}$.

W wyniku analizy zawartości treści dwóch pierwszych dekad funkcjonowania tzw. ,wolnych” mediów lokalnych w wydawniczym regionie leszczyńskim, można zauważyć, iż informacja z kategorii „polityka lokalna" (np. tłem są rozgrywki w radzie gminy, radzie powiatu), stanowi najbardziej jaskrawy przykład zaangażowania mediów w tabloidyzację informacji. Podobnie, istnieje swoisty schemat prezentowania relacji $\mathrm{z}$ masowych imprez. Podstawowym przekazem są wielkoformatowe zdjęcia osób znanych we wspólnocie lokalnej i mieszkańców tejże wspólnoty (często zajmujące kilka stron - pierwszą i środkowe), podpisanych kilkoma mniej znaczącymi informacjami (tzw. informacje miękkie - sensacja, rozrywka, tandeta), a dające wyraz ich zaangażowania w uczestniczenie w określonych wydarzeniach medialnych (np. miejskich i wiejskich uroczystościach organizowanych systematycznie). Atutem mediów lokalnych jest opisywanie procesów, zjawisk, wydarzeń, osób będących blisko mieszkańca danej wspólnoty. To decyduje o sprzedaży nakładu. Tabloidyzacja ze swoimi cechami typowymi dla informacji popularnej (za Stephenem Harringtonem - „tabloid, informacje miękkie, śmieci”

123 C. Sparks, Introduction: the panic over tabloid news, w: Tabloid Tales. Global Debates over Media Standards, red. C. Sparks, J. Tulloch, Lanham: Rowman \& Littlefield, 2000, s. 10-11. W ujęciu pierwszym - w dziennikarstwie prasowym, radiowym i telewizyjnym tabloid oznacza formę - dominują dwie cechy - relatywnie mało uwagi poświęca się polityce, ekonomii i społeczeństwu, a relatywnie więcej - rozrywce (sport, skandal, popularne widowiska) oraz poświęca się relatywnie dużo uwagi osobistemu i prywatnemu życiu ludzi: zwyczajnych i znanych, a relatywnie mniej - politycznym procesom, rozwojowi ekonomicznemu czy zmianom społecznym. W drugim ujęciu - zmiana priorytetów w konkretnym medium i rosnąca przewaga rozrywki, a dotyczy to głównie radia i telewizji. Po trzecie - przekroczenie dobrego smaku w różnych formach przekazu.

124 D. Piontek, Komunikowanie polityczne i kultura popularna. Tabloidyzacja informacji o polityce, Poznań 2011, s. 189. 
- w opozycji do „wartości, osobiste, prywatne, kultura popularna, emocjonalne, wiedza potoczna, celebracyjne, konsument, trywialne, żeńskie, zysk, mikropolityka, żądania"125), sprzyja sprzedaży nakładu pisma lokalnego, bowiem ludzi ciekawi najbardziej to, co dzieje się w ich przestrzeni życiowej - parafrazując - za płotem ich domostwa. Jednak zbyt duża zawartość informacji miękkich lub nie do końca zgodnych z obyczajowością czytelnika może doprowadzić do likwidacji tytułu.

Forma informacji tabloidalnej w badanych materiałach odnośnie sportowych pasji kobiet, w zdecydowanej większości, dotyczyła przekazów związanych z Euro 2012, aniżeli w przypadku prezentowania innych tematów z kategorii ,sport”. Chociaż dosyć interesująco rozpisywano się zarówno w mediach lokalnych drukowanych, jak i elektronicznych o sukcesach Anity Włodarczyk (np. Radio Elka informowało - „Nie ma mocnych na Beatę Włodarczyk” ${ }^{26}$ lub „Rawicka młociarka wygrywa bijąc życiówki”"127) lub zaprezentowano na okładce „Panoramy Leszczyńskiej" zdjęcia zajmującego całą stronę - chłopca na wózku inwalidzkim, kierowanym przez matkę, na stadionie żużlowym, z tytułem wyróżnionym czcionką - Dziennikarze spetnili marzenie Krzysia ${ }^{128}$. Na pierwszych, środkowych i ostatnich stronach czasopism regionalnych i lokalnych pojawiały się głównie informacje związane z Euro 2012, z tytułami mającymi duży wydźwięk emocjonalny (np. Mieliśmy puchar przed Hiszpana$m i !^{129}$ i Kosztowny bojkot z komentarzem pod zdjęciem mobilnej strefy kibica Euro 2012 w Lesznie - „widzów było mniej niż pracowników obsługi" ${ }^{130}$ ). Typowymi informacjami „miękkimi” były publikacje nawiązujące do Euro 2012, a dotyczące m.in. zabójstwa w Tarnowie Podgórnym, w godzinach po zamknięciu strefy kibica (34-letni mężczyzna zamordowany $w$ bójce ${ }^{131}$ ), korupcji (Ukraińskie Euro petne korup-

125 Ibidem, s. 187.

126 Piętnaste złoto Beaty Włodarczyk, http://elka.pl/content/view/61257/58/, 2.12.2012.

127 Rawicka młociarka wygrywa bijąc życiówki, http://elka.pl/content/view/ 25448/137/, 02.12.2012.

128 A. Machowska, Spetnione marzenie Krzysia, „Panorama Leszczyńska”, nr 24, 14.06-20.06.2012, s. 1 i 44.

129 A. Muenzberg-Czubała, Mieliśmy puchar przed Hiszpanami!, „Gazeta Kościańska", nr 27, 4 lipca 2012, s. 1, 16-17.

130 Kosztowny bojkot, „Panorama Leszczyńska”, nr 25, 21.06-27.06.2012, s. 1.

131 34-letni mężczyzna zamordowany w bójce, „Głos Wielkopolski”, 11.06.2012, s. 12 . 
cji ${ }^{132}$ ), prostytucji (Spałam z księciem - mówi Magda. Jak z modelek zrobiono prostytutki ${ }^{133}$ ), urody (Najwięcej witaminy maja Polki ${ }^{134}$ ) oraz instrukcji - jak zrobić makijaż na Euro 2012 (Jak mieszkanka Leszna zarabia na filmach $w$ sieci ${ }^{135}$ ). W związku z tego typu informacjami, szczególnie zapamiętane zostały też takie tytuły publikacji, jak - Kierowcy stoja w korkach a drogowcy się bawiq ${ }^{136}$, Euro w Poznaniu, czyli kleszcze, prostytutki i smutni urzędnicy ${ }^{137}$ i Droga na Euro - droga seksu ${ }^{138}$.

Nie zabrakło specjalnych, nowych form graficznych, przyciagających wzrok czytelnika, nie wykorzystywanych wcześniej (np. w tytule „Panorama Leszczyńska” litera „„” została zastąpiona zdjęciem piłki nożnej, w tym samym numerze - pogrubiona i zwiększona czcionka na okładce odnośnie informacji o „Dodatku Euro 2012”"139 lub prezentowanie zdjęć kibiców na stronach pierwszych i kolejnych ${ }^{140}$ ). Euro 2012 miało przyczynić się do zwiększenie popytu na media lokalne i regionalne, na co wskazuje ekspozycja materiałów prasowych. Wspomniany udział kobiet w Euro 2012, miał podnieść nie tylko wrażenia związane z estetyką tytułu lokalnego czy regionalnego, ale również przyczynić się do zwiększenia sprzedaży nakładu.

Female sporting passions. A contribution to qualitative studies into the content of the regional and local press in Wielkopolska and surrounding areas

\section{Summary}

Studies into the content of the local and regional press expand our knowledge about the life of local communities. The author limits herself to studying the narrow

\footnotetext{
132 Ukraińskie Euro petne korupcji?, „Głos Wielkopolski”, 04.06.2012, s. 17.

133 M. Rybak, M. Moczulska, Spałam z księciem - mówi Magda. Jak z modelek zrobiono prostytutki, „Głos Wielkopolski”, 4.06.2012, s. 14.

134 A. Jarmuż, Najwięcej witaminy maja Polki, „Głos Wielkopolski”, Magazyn, 16.06.2012. s. 5 .

135 K. Koziolek, Jak mieszkanka Leszna zarabia na filmach $w$ sieci, „Głos Wielkopolski”, 30.06.2012, s. 7.

136 Kierowcy stoja $w$ korkach a drogowcy się bawiq, „Fakt” - Poznań, 20.06.2011, s. 1 .

137 Euro w Poznaniu, czyli kleszcze, prostytutki i smutni urzędnicy, „Echo Miasta" - Poznań, 4.06.2012, s. 8.

138 Droga na Euro - drogq seksu, „Tygodnik Śremski”, 15.06.2012, s. 2.

139 Dodatek Euro 2012, „Panorama Leszczyńska”, nr 24, 14.06-20.06.2012, s. 1, 47-48.

140 My, biało-czerwoni, „ABC”, nr 45, 12.06-14.06.2012, s. 1, 2, 4 i 14.
} 
issue of women's sporting interests, whereby she analyzes their active (as athletes and trainers) and passive (administering various sports, as fans) participation in amateur and professional sport. The paper also indicates which factors are decisive for the domination of a given sport in a region and considers to what extent the picture presented is true, reflects reality and exhausts all aspects of women's interest in sport. The way in which press materials are presented is also interesting and confirms the observation that local and regional media have become tabloidized to a greater or lesser degree (depending on the type of periodical). The qualitative study has shown that women's need to practice sport is not only an expression of their emancipation, a development of their skills, and a desire to break records, but at present it has primarily become a way of living a 'healthy life'. The local and regional press fulfill two roles in this regard: they provide a wider presentation of professional and amateur sport and, to a lesser degree, persuade their readers to practice sport themselves (propagating a 'healthy lifestyle' accounts for an average of two articles out of eighteen qualified as 'sport articles'). The research field encompassed a wide range of female sporting passions, while the examples discussed confirm that women live active lives. 